\title{
Agricultural Water Pricing: Australia
}
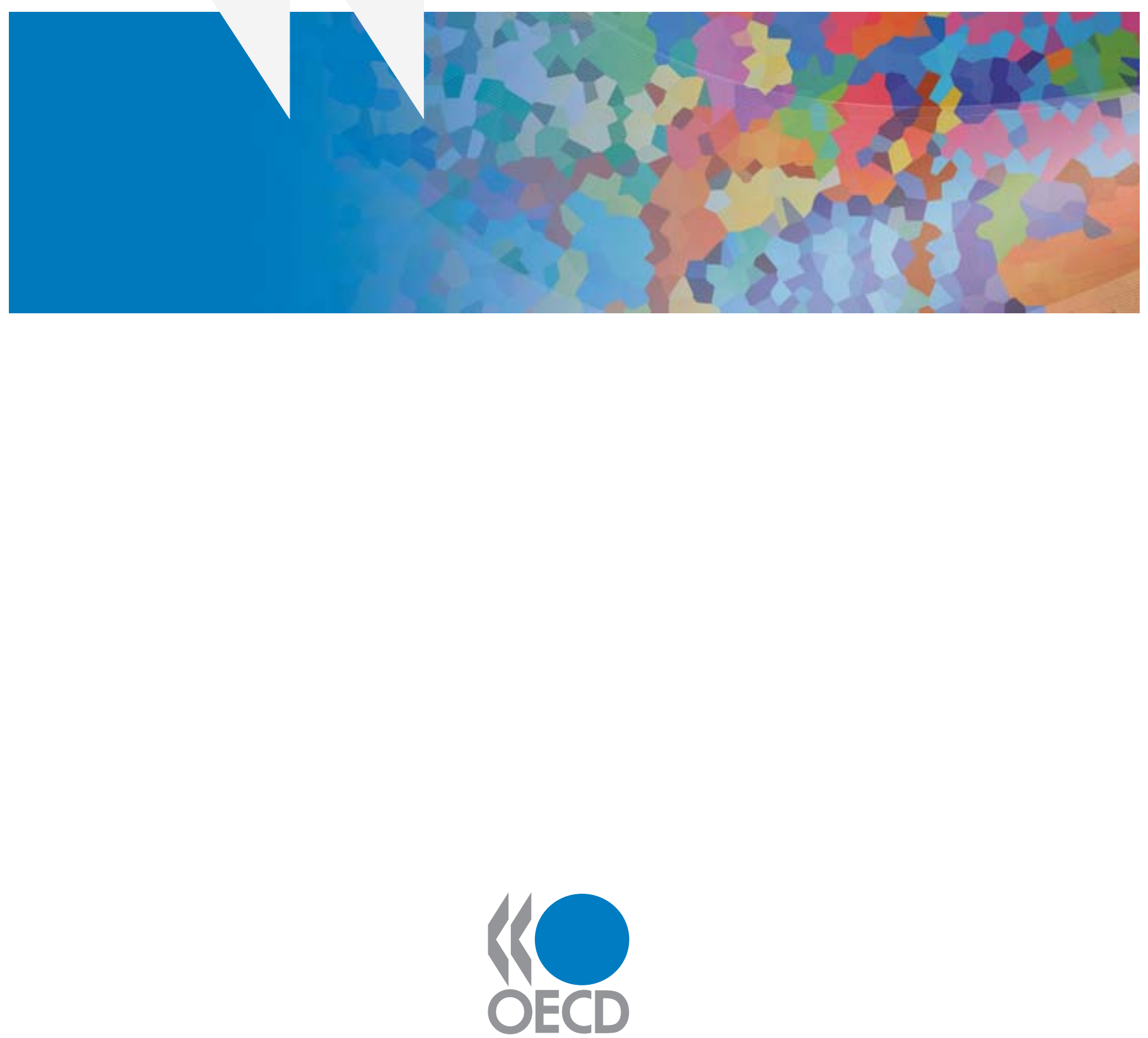


\section{ORGANISATION FOR ECONOMIC CO-OPERATION AND DEVELOPMENT}

The OECD is a unique forum where the governments of 30 democracies work together to address the economic, social and environmental challenges of globalisation. The OECD is also at the forefront of efforts to understand and to help governments respond to new developments and concerns, such as corporate governance, the information economy and the challenges of an ageing population. The Organisation provides a setting where governments can compare policy experiences, seek answers to common problems, identify good practice and work to co-ordinate domestic and international policies.

The OECD member countries are: Australia, Austria, Belgium, Canada, the Czech Republic, Denmark, Finland, France, Germany, Greece, Hungary, Iceland, Ireland, Italy, Japan, Korea, Luxembourg, Mexico, the Netherlands, New Zealand, Norway, Poland, Portugal, the Slovak Republic, Spain, Sweden, Switzerland, Turkey, the United Kingdom and the United States. The Commission of the European Communities takes part in the work of the OECD.

(C) OECD 2010 


\title{
Agricultural Water Pricing: Australia
}

\author{
SEAMUS PARKER \\ COUNCIL OF MAYORS (SOUTH-EAST QUEENSLAND) \\ ROBERT SPEED \\ FREELANCE CONSULTANT
}

AUSTRALIA 


\section{Note}

This document, Agricultural Water Pricing: Australia, by Seamus Parker, Council of Mayors (SouthEast Queensland) and Robert Speed, Freelance Consultant, Brisbane, Australia, is one of the background reports supporting the OECD study (2010) Sustainable Management of Water Resources in Agriculture, which is available at www.oecd.org/water.

The report was carried out under the auspices of the OECD Joint Working Party on Agriculture and the Environment of the Committee for Agriculture and the Environment Policy Committee. The report is published under the responsibility of the author and does not necessarily reflect the views of the OECD or its member countries.

The other background reports (also available at www.oecd.org/water) are:

An Economic Analysis of the Virtual Water Concept in Relation to the Agri-food Sector Dennis Wichelns, Hanover College, United States http://dx.doi.org/10.1787/786736626756

Agriculture's Role in Flood Adaptation and Mitigation - Policy Issues and Approaches Joe Morris, Tim Hess and Helena Posthumus, Cranfield University, United Kingdom http://dx.doi.org/10.1787/786804541573

Environmental Effectiveness and Economic Efficiency of Water Use in Agriculture: The Experience of and Lessons from the Australian Water Reform Programme Michael D. Young, University of Adelaide, Australia http://dx.doi.org/10.1787/786732081512

Financing Water Management and Infrastructure Related to Agriculture across OECD Countries Frank A. Ward, New Mexico State University, United States http://dx.doi.org/10.1787/786788524232

Agricultural Water Pricing: EU and Mexico Alberto Garrido, Universidad Politécnica de Madrid; and Javier Calatrava, Universidad Politécnica de Cartagena, Spain http://dx.doi.org/10.1787/787000520088

Agricultural Water Pricing in Japan and Korea James E. Nickum and Chisa Ogura, Asian Water and Resources Institute, Japan http://dx.doi.org/10.1787/787011574235

Agricultural Water Pricing in Turkey

Erol H. Cakmak, Middle East Technical University, Turkey http://dx.doi.org/10.1787/787034266022

Agricultural Water Pricing: United States Dennis Wichelns, Hanover College, United States http://dx.doi.org/10.1787/787165082115 


\section{Table of Contents}

Executive Summary...................................................................................... 6

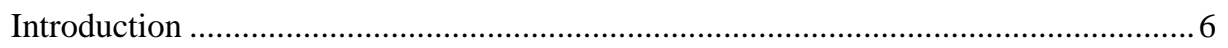

The nature of agricultural water supplies ........................................................... 7

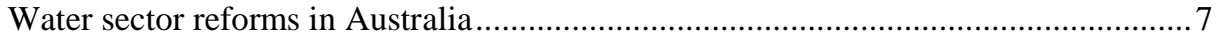

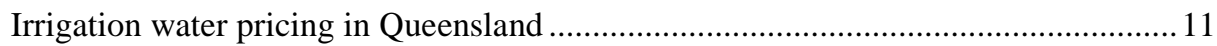

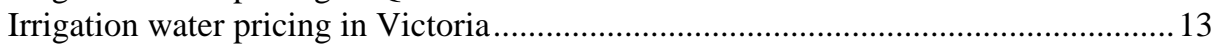

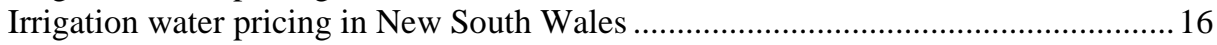

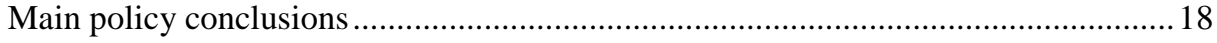

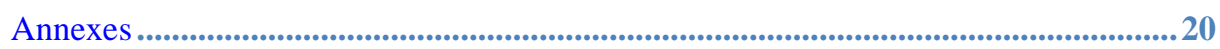

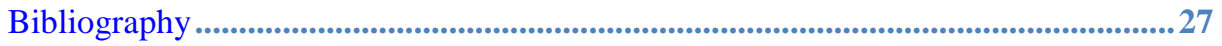




\section{Executive Summary}

In the early 1990s, governments in Australia and the irrigated agriculture sector were confronted with a number of fundamental challenges. Prices being paid by farmers for irrigation water delivery were generally not covering the costs of supply, the government owned irrigation infrastructure was not being managed in a commercial manner, water entitlements were poorly defined, and the health of rivers and aquifers in many parts of the country was deteriorating.

Within the Australian federal system, the State governments have constitutional responsibilities for water management, and own much of the irrigation infrastructure. However, the scale and significance of the issues necessitated a national approach, and in 1994 the Council of Australian Governments (COAG), comprising the Prime Minister and leaders of the States and Territories agreed on a response. Importantly, the water resources policy was seen as part of a broader microeconomic reform agenda that included reforms to such diverse areas as road transport and regulation of occupations.

Water pricing was one element of the agenda, another being the institutional separation of service delivery from regulation. State-owned irrigation schemes became commercially focussed - either through becoming government owned corporations, or being transferred to users to own and operate. The States committed to "lower bound pricing", meaning water prices covered the operation, maintenance and refurbishment costs of supply - but not a commercial return on the assets. Water businesses were established, farmers became customers and water became a product. The subsidies of years past became explicit, and price paths were developed to remove them. State governments received incentive payments from the Australian Government if policy outcomes were met.

A new body, the National Competition Council (NCC), was established and it assessed each State's performance in water and the other areas of micro-economic reform. States met the new water pricing policy objectives, though the timeframes for implementation varied depending largely on the extent of the price increases necessary. A small number of schemes which simply were not economically viable continued to receive explicit and transparent community service obligation payments.

In 2004, the water sector reforms were refreshed with the National Water Initiative (NWI) building on progress since 1994. The National Water Commission (NWC) was established as a statutory body to drive the reforms and provide advice to COAG. The NWC assumed responsibility for assessing States performance on pricing reforms, and its 2005 assessment of progress found States had met the lower bound targets (NWC, 2006). While water pricing is now at lower bound, both irrigation and urban water pricing reforms continue to be a key element of the NWI, with a focus on developing nationally consistent approaches to matters such as capital recovery and the identification of water planning and managements costs.

\section{Introduction}

This paper is a study of agricultural (irrigation) water pricing in Australia. It examines agricultural water price ranges and characteristics, and the extent to which the price paid by irrigators recovers operation, maintenance and capital costs for water delivery to the farm (i.e. cost of supply).

The paper provides a brief overview of water management arrangements in Australia and outlines the national principles that have been adopted to guide water pricing (including for agricultural water) across the States. The paper then provides a detailed review of the water pricing approach in a number of different States. For each State, the institutional arrangements are described (in respect of water management, water supply, and price setting responsibilities) as well as the way prices have been determined, the prices themselves, and the extent to which these prices reflect actual cost of supply.

For various political, historical and physical reasons, there are significant regional variations (even within States) in prices. Within a State, there can be dozens of water supply schemes, some with different owners, with different pricing methodologies and tariffs. It can then be difficult to be either categorical or exhaustive in describing how water prices are set and their level. This paper endeavours to provide an overview of the principles underpinning agricultural water pricing in Australia, together with specific examples from some of the key, and representative, regions and water supply schemes. 
In assessing the water prices and the extent to which they recover the costs of supply, privately owned irrigation schemes have not been included. However, the costs of wholesale or bulk water from government owned assets to these schemes has been assessed. Detailed data is presented for irrigation water supplied in Queensland, New South Wales and Victoria, which between them account for around $85 \%$ of irrigated agriculture by volume of water supplied (ABS, 2008). In the States of South Australia and Western Australia, the major irrigation schemes and owned and operated by companies owned by the irrigators.

As part of the reforms in Australia, water businesses have been institutionally separated from the regulatory bodies. The irrigation assets (dams, pipes, channels) have been moved from government departments to stand alone businesses with a commercial focus. Agriculture water prices should cover the costs of those businesses - in Australia these prices are referred to as water storage and delivery charges (NWC 2007a).

This separation has meant that planning and managing water resources is undertaken by government agencies, with the associated costs met by the government, with some recovery through licence fees or other charges paid by water users. This paper does not assess the extent to which these costs are recovered from agricultural water users (NWC, 2007b). However, recovery of these costs is fundamental to ensuring the use of water resources is planned and managed, and water is properly valued.

\section{The nature of agricultural water supplies}

Agricultural water users in Australia can be split into two categories: those supplied from a water supply scheme (typically comprising large scale and common infrastructure such as channels) and those supplied from private infrastructure (for example, pumps to extract from rivers and on-farm diversions built and operated by farmers at their own expense). In Queensland, for example, around 50\% of agricultural water use is supplied from farmer-built and owned infrastructure, where the farmer directly pays both the capital and operational costs. As such there are no water storage and delivery charges paid and therefore this type of water use is not considered in this paper

In both cases, water users usually require some form of authorisation to take water. Even within water supply schemes, end-users (the farmers) will generally hold some form of access entitlement, either directly or as a share of the scheme's bulk water entitlement. This policy position was adopted as part of the national water reform process to encourage efficiency and allow water trading. Scheme operators are usually required to operate their scheme and supply users in accordance with an operations licence. Supply contracts between the scheme operator and the farmer typically set the conditions of supply.

Historically, the entitlements to water from water supply schemes were granted to farmers for free; these were mostly regional development initiatives, and farmers were encouraged to develop their land to utilise the available water. More recently, where new water supply schemes have been built, entitlements to the water from the scheme have been sold, for example by auction.

In the past, the operational costs of water supply schemes were heavily subsidised by government, often reflecting broader policy objectives around regional development. More recently, there has been a shift to increase the charges paid by farmers to the supply scheme operator. In a number of States, supply schemes have now been privatised, via a variety of different legal mechanisms, with ownership passed to the irrigators within the scheme. (Typically it has been only the channel systems that have been passed over, and not the bulk water supply assets, such as reservoirs).

\section{Water sector reforms in Australia}

In Australia, the States have (for the most part) constitutional responsibility for the management of their water resources $^{1}$. In practice, the Australian government has exerted pressure on the States to change water management practices via financial incentives, principally through various agreements between the State and Australian governments.

\footnotetext{
${ }^{1}$ Recently, COAG agreed that some States would refer powers to the Australian Government to assume responsibility for aspects of water allocation and management within the Murray-Darling river system. COAG consists of the Prime Minister, the State Premiers, the Territory Chief Ministers and President of the Local Governments Association of Australia.
} 
The agreement of the Council of Australian Governments ('COAG') on water reform, reached in 1994 as part of the implementation of the National Competition Policy, was the catalyst for water reform in Australia (NCC, 1998). The agreement set out a framework for all States to work towards, with the goal of establishing an efficient and sustainable water industry. In 2004 the same parties entered the National Water Initiative ('NWI'), which built upon the reform agenda set out in the 1994 COAG Agreement (COAG, 2004). COAG continues to be a key forum for water sector reform.

The Australian agricultural sector has been subject to fundamental reforms to the institutional arrangements for water supply and water pricing since 1994. It has meant that while individual States have (generally) remained responsible for management of their own water resources, the water management principles applied across the country have been the same. These have included:

- the development of water resource plans, underpinned by robust science and hydrology modelling, as the basis for allocation decisions;

- the recognition of the need for water for environmental purposes;

- separation of regulatory and operational functions in institutional arrangements;

- granting secure entitlements to water, where possible to the end-user;

- allowing for trading of those entitlements between users; and

- cost reflective pricing of water supply.

More recently, the Australian Government has developed a strategy to secure Australia's long term water supply. The 'Water for the Future' program will invest $\$ 12.9$ billion over 10 years in water buybacks, infrastructure and policy reforms. The program includes $\$ 3.1$ billion for purchasing water entitlements in the Murray Darling Basin to return to the river, and $\$ 450$ million for improving water information systems.

\section{Defining and recovering the costs of irrigation water}

The 1994 COAG agreement included general principles for pricing, including consumption-based pricing, full-cost recovery and (desirably) the removal of cross-subsidies. In respect of rural water supply, the agreement provided for a move to full cost-recovery and to achieve positive real rates of return on the written-down replacement costs of assets in rural water. The parties agreed to aim to implement this new pricing regime by 2001 .

Further advancing these goals, the 2004 NWI required that the parties:

- promote economically efficient and sustainable use of water resources, water infrastructure assets, and government resources;

- $\quad$ ensure sufficient revenue streams to allow efficient delivery of the required services;

- facilitate the efficient functioning of water markets; and

- give effect to the principles of user-pays and achieve pricing transparency in respect of water storage and delivery in irrigation systems and cost recovery for water planning and management ${ }^{2}$.

The agreement specifically provided for consumption based pricing, coupled with full cost recovery for water services, to ensure business viability and avoid monopoly rents, including (where feasible and practicable) the recovery of environmental externalities. It requires:

- full cost recovery (save some small community services) with:

- lower bound pricing;

- a move towards upper bound pricing, where practicable; and

\footnotetext{
${ }^{2}$ National Water Initiative, clause 64.
} 
- public reporting of subsidies where full cost recovery is unlikely to be achieved in the long term;

- recovery of water planning and management costs, through:

- identification of costs associated with water planning and management; and

- identification of the proportion of those costs that can be attributed to water access entitlement holders;

- future investment in water infrastructure to be assessed as economically viable and ecologically sustainable prior to investment occurring;

- annual independent, public report benchmarking of pricing and service quality for rural water delivery agencies;

- $\quad$ an independent pricing regulator together with regular review and public reporting.

The NWI included the following key definitions in respect of pricing:

- lower bound pricing - the level at which to be viable, a water business should recover, at least, the operational, maintenance and administrative costs, externalities, taxes or tax equivalents regimes (TERs) s (not including income tax), the interest cost on debt, dividends (if any) and make provision for future asset refurbishment/replacement. Dividends should be set at a level that reflects commercial realities and stimulates a competitive market outcome;

- upper bound pricing -the level at which, to avoid monopoly rents, a water business should not recover more than the operational, maintenance and administrative costs, externalities, taxes or TERs, provision for the cost of asset consumption and cost of capital, the latter being calculated using a weighted average cost of capital (WACC) $)^{3}$.

The different States have adopted various methods to achieving these goals. The following parts include examples of the approaches in Queensland, New South Wales and Victoria. The implementation of these principles is also at various stages of completion, particularly due to the political sensitivities associated with increasing water charges. In many instances, States have adopted price paths, typically for 5-year periods, to incrementally move towards full-cost recovery prices.

\section{Efficient delivery of irrigation water - National Performance Reports}

Increasing water prices is not of itself a sufficient policy response to promote efficiency in use and delivery. In recognition of this, the NWI provides for benchmarking of service providers.

Annual performance reports for water service providers are compiled by the National Water Commission as part of a benchmarking exercise. The first of these reports for rural water services was completed for the 2006-07 financial year (NWC, 2008). The report includes details for all major rural water service providers in Australia, and includes information for each service provider, as well as for each supply scheme, on:

- $\quad$ system characteristics: type and size of system, customer numbers;

- customer service indicators: complaint numbers, etc.;

- environmental indicators: electricity consumption and greenhouse gas emissions;

- financial indicators: asset value (replacement and depreciated value), revenues (including for different tariff components), payments for community service obligations (i.e. subsidies), as well as capital, operational and administrative expenditure.

\footnotetext{
${ }^{3}$ National Water Initiative, clauses 65-77.
} 


\section{Water Act 2007 (Cth) and water charges}

The Australian Government has recently assumed a more hands-on role in water resources management, via the Water Act 2007 (Cth). Through a referral of powers from the States, the Act establishes a basis for the Australian Government to take a greater role in the management of the Murray Darling basin, principally through the development of a whole-ofbasin water resource plan.

The Act also provides for the regulation of water storage and delivery charges within the basin, via "water charge rules", to be made by the Federal Minister for Climate Change and Water. The Australian Competition and Consumer Commission is charged with providing advice to the Minister on the water charge rules by June $2009^{4}$. The Act includes water charging principles and objectives, which are to be applied in formulating the water charge rules ${ }^{5}$. These principles and objectives are based on the pricing principles in the NWI. Notably, the principles require that water charges should continue to move towards upper bound pricing where practicable.

In July 2008 COAG agreed to an Intergovernmental Agreement on Murray-Darling Basin Reform (IGA). The IGA's central principle is to improve planning and management by addressing the Basin's water and other natural resources as a whole, in the context of a Commonwealth-State partnership. The IGA, once implemented, will strengthen the role of the ACCC in regulating the water charge rules by:

- extending their application to more entities;

- ensuring that determinations can be made for all water charges regulated under the Water Act; and

- providing states and territories with the opportunity to extend the application of the water charge rules to areas outside of the Basin.

\section{Summary of cost recovery for supply of irrigation water}

While the States have been slower than originally anticipated in achieving lower bound pricing (the 1994 COAG originally set a target of 2001), this goal has now been realised in the vast majority of government-owned water supply schemes.

Where government entities are required to provide water supply services to irrigators at a price that is less than lower bound levels, the balance is paid by government as a transparent community service obligation ('CSO') payment. The level of these payments represents the extent to which the different entities are not yet achieving lower bound pricing. In summary:

- in Queensland, SunWater currently (for 2008/09) receives less than 5\% of its revenue as a CSO payment. That amount will halve by the end of the current price path, in 2010/11;

- in Victoria, the three major rural water supply authorities currently receive no CSO payments (i.e. all are currently at or above lower bound levels). Water authorities receive a return on net capital, using a weighted average cost of capital approach;

- in New South Wales, State Water Corporation will achieve lower bound pricing by 2009/10 in basins that represent over $95 \%$ of the water that it supplies.

Governments have recognised that there are a small number of schemes, representing a small volume of the total water supplied, that are not, and probably will never be, economically viable in their own right. In these instances, the schemes will continue to be supported through a transparent CSO payment.

\footnotetext{
${ }^{4}$ Water Act 2007 (Cth), sections 91-96.

${ }^{5}$ Water Act 2007 (Cth), schedule 2.
} 


\section{Irrigation Water Pricing in Queensland}

In Queensland, the majority of water for irrigation purposes is supplied by SunWater, a State government owned corporation. SunWater owns and operates 27 water supply schemes, which supply over 5,500 customers, the vast majority of them irrigators. There are a small number of other government authorities that also supply irrigation water. SunWater's supply schemes are primarily made up of regulated river systems and gravity fed channel distribution systems.

Table 1. Overview of SunWater's Assets and Financials

\begin{tabular}{l|l|l}
\hline Infrastructure & Number of services & 36 \\
\cline { 2 - 3 } & Regulated river & $3,637 \mathrm{~km}$ \\
\cline { 2 - 3 } & Channel & $873 \mathrm{~km}$ \\
\cline { 2 - 3 } & Pipes & $1087 \mathrm{~km}$ \\
\cline { 2 - 3 } & Customers & 5,852 \\
\cline { 2 - 3 } & Volume supplied & $1,047,399 \mathrm{ML}$ \\
\hline \multirow{2}{*}{ Financials } & Revenue from rural water services & $\$ 40$ million \\
\cline { 2 - 3 } & Operational expenditure & $\$ 17.6$ million \\
\cline { 2 - 3 } & Administration expenditure & $\$ 13.8$ million \\
\cline { 2 - 3 } & Maintenance expenditure & $\$ 16.5$ million \\
\cline { 2 - 3 } & Capital expenditure & $\$ 9.1$ million \\
\hline
\end{tabular}

Source: NWC (2008)

The Queensland Department of Environment and Resource Management is responsible for management of the State's water resources. It is responsible for preparing water resource plans and resource operations plans for each catchment, which define the total volume available for allocation from a supply scheme and are the basis for granting entitlements to that water ${ }^{6}$. In most cases, water entitlements ${ }^{7}$ are granted to the individual water users, although in some instances water entitlements can be held by the scheme owner (e.g. SunWater).

The Department also has regulatory oversight of SunWater, to ensure it complies with the relevant water resources plans, its operational licences and strategic asset management plans. The Water Act (section 121) requires that all water users have a supply contract with their water supplier.

SunWater is responsible for setting prices (following consultation with water users). Oversight of water prices is provided by the Queensland Competition Authority ('QCA'), an independent authority established to investigate and report on the pricing practices of monopoly business activities of State and local governments. Under part 5A of the Queensland Competition Authority Act 1997 (Qld), the QCA also has responsibility to mediate and/or arbitrate access disputes and water supply disputes.

\footnotetext{
${ }^{6}$ Water Act 2007 (Qld), part 3.

${ }^{7}$ In Australia, different States use different terminology to describe the (long-term) right to take water. Both "water entitlement" and "water access entitlement" are used.
} 


\section{Water pricing methodology}

In June 2006 SunWater released its water tariffs for the period 2006 to $2011^{8}$. The prices were determined within the pricing framework set out by the Queensland government policy, which in turn mirrored the obligations in the NWI. This required that most schemes achieve lower bound pricing by the end of the price path.

The five-year price paths were the result of a two-step process. Firstly, in conjunction with irrigators and peak industry groups, efficient lower bound costs for the irrigation component of SunWater's water supply schemes were defined and a series of reference irrigation tariffs set. Secondly, and in conjunction with representatives from each water supply scheme, the results of the first stage were applied to decide tariffs for each scheme, based on a consideration of local issues. In addition this stage involved discussions on the form of price control (revenue cap or price cap), customer standards and irrigation water usage forecasts.

Broadly, the process consisted of:

- determining service standards - which in turn affected supply costs and thus lower bound costs;

- determining SunWater's efficient lower bound costs: an independent consultant was engaged to undertake a cost and efficiency review of SunWater's business costs. The process involved a benchmarking exercise to establish benchmarks at both a state-wide and scheme level for comparison with SunWater's actual cost data;

- ring-fencing those activities not associated with management of water supply schemes - for example consulting services, hydropower generation, etc.;

- apportioning direct and indirect costs across the schemes - indirect costs included head and regional office costs (as distinct from the direct operation and maintenance of the supply scheme). In simple terms, this was done by apportioning indirect costs based on the levels of each scheme's direct costs;

- apportioning individual scheme costs between water supply and other purposes - e.g. where a scheme was designed both for water supply and for flood management purposes, a portion of the management costs were assigned to the flood management function;

- apportioning water supply costs between irrigation and non-irrigation customers - lower bound costs were then apportioned between customer groups based on the nominal allocation for each group, with an adjustment based on the priority of supply (i.e. a group with a higher priority of supply was apportioned a higher percentage of the lower bound costs).

At an individual water supply scheme level, the costs apportioned were then converted to a tariff, based on consideration of likely water usage (i.e. what percentage of the nominal allocation would likely be used each year) and local preferences (including whether the irrigators for the scheme wanted a variation in the customer service standards).

\section{Tariff structures}

The individual schemes have different supply characteristics - water supply reliability, industry base, customer numbers, and infrastructure types - which results in variations both in the type and magnitude of tariffs. All except one of SunWater's 27 schemes operate under a 2-part tariff system: consisting of "Part A" (fixed) charges and a variable "Part B" charge.

As part of setting the price paths, initial "reference tariffs" were developed. These were based on a tariff structure whereby the Part A tariff was set to recover $70 \%$ of lower bound costs, with the Part B tariff to recover the remaining $30 \%$. The independent review found that SunWater's fixed costs average around $93 \%$ of the total lower bound costs. The reference tariffs were thus developed using projected water usage, to provide the required average revenues over time (and thus to ensure that the risk of below-cost revenues in times of drought were balanced by higher returns in other years).

\footnotetext{
${ }^{8}$ Details of the negotiations leading to new prices, including reports and working papers on tariff design can be found at http://www.sunwater.com.au/irrigationpricing.htm.
} 
The reference tariffs were then adjusted (in terms of the percentage of costs attributed to part A and part B) based on discussions with local irrigators to determine the mix that best suited local circumstances. The adjustment involved balancing:

- the benefits to irrigators and SunWater of a relatively fixed price to pay (providing certainty);

- the benefits (to irrigators) of paying less when water use is less, as these are usually also times of low income (due to drought).

The vast majority of SunWater schemes operate under a "price cap": that is, the part A and part B charges are fixed. Under this pricing model, there is greater fluctuation in the revenue as water use goes up and down. As an alternative, irrigators were offered the option of a revenue cap, which fixes the revenue paid by irrigation customers. This is designed to remove the risks to users and SunWater associated with forecasting water use to achieve revenue targets. Only three SunWater schemes opted to adopt a revenue cap on Part B charges. Annex 1 shows the current water tariffs for SunWater's major schemes.

\section{Cost recovery and community service obligations}

Government subsidies to SunWater are paid by way of transparent community service obligation ('CSO') payments. These payments reflect the extent to which revenue from different schemes is below lower bound: as such they provide a clear benchmark of the level of cost recovery.

In 2006/07, SunWater received approximately $\$ 5.6 \mathrm{~m}$ in subsidies for rural water supply, representing $14 \%$ of total revenue. Scaling back of CSO payments (as a result of increases in water tariffs and thus water supply revenue) mean this will fall below $5 \%$ in 2008/09, and further still in coming years.

Table 2. Community service obligation payments to SunWater

\begin{tabular}{|c|c|c|c|c|c|}
\hline & $\mathbf{2 0 0 6 / 0 7}$ & $\mathbf{2 0 0 7 / 0 8}$ & $\mathbf{2 0 0 8 / 0 9}$ & $\mathbf{2 0 0 9 / 1 0}$ & $\mathbf{2 0 1 0 / 1 1}$ \\
\hline Rural water supply & $5,593,138$ & $3,280,533$ & $1,850,224$ & $1,448,516$ & $1,047,383$ \\
\hline
\end{tabular}

Source: SunWater (2006)

\section{Irrigation Water Pricing in Victoria}

Irrigation water in Victoria is principally supplied by three State owned rural water businesses: Goulburn-Murray Water Rural Water Corporation ('Goulburn-Murray Water'), Gippsland and Southern Rural Water Corporation and First Mildura Irrigation Trust.

The Victorian Department of Sustainability and the Environment is responsible for managing the State's water resources. It grants bulk water entitlements to the rural (and urban) water businesses. The bulk water entitlements set the system limits and require the holder of a bulk entitlement to supply the other entitlements held within the system. In the case of a rural water business, these other entitlements typically comprise bulk entitlements for urban areas (held by regional water authorities) and water access entitlements held by irrigators (as customers of the rural water business) ${ }^{9}$.

The Victorian Essential Services Commission ('ESC') is responsible for the economic regulation - including regulating prices and service standards - of the Victorian water sector, including both urban and rural water services. Significantly, in Victoria, water access entitlements (i.e. an irrigator's right to a share of the available water resource) and delivery rights (a right to a share of the capacity of a distribution system) have been unbundled. Consequently, irrigators in Victorian supply schemes hold both a water access entitlement and a delivery share. The unbundling process has (necessarily) been applied to the water pricing regime, with different charges attached to each of these two elements.

The system allows for greater freedom for an irrigator to sell their water share outside of the scheme's delivery system, while ensuring someone (whoever owns the delivery share) remains liable for the fixed charges associated with the delivery share, thus contributing to operation and maintenance of the delivery assets. This approach protects a water

\footnotetext{
${ }^{9}$ Water Act 1989 (Vic.); Water Industry Act 1994 (Vic.).
} 
supply scheme owner from the risk of lost revenue as a result of water access entitlements being traded out of the scheme and reducing the scheme's revenue (i.e. the issue of stranded assets). It also provides a more cost-reflective approach to addressing the issue of capacity constraints associated with peak delivery periods. In other Australian states, typically an "exit fee" must be paid before a water entitlement can be transferred out of a supply scheme, to protect the revenue base of the supply scheme operator.

\section{Water pricing methodology}

The Water Industry Regulatory Order 2003 (WIRO) ${ }^{10}$ specifies both the procedural and regulatory requirements for water price-setting, including the level of cost recovery required of State water businesses and their assets. The WIRO requires rural (and urban) water businesses to prepare "Water Plans". These plans propose water prices and demonstrate how the prices will ensure sufficient revenue to meet their service requirements (i.e. in terms of maintaining and operating the necessary delivery infrastructure), as well as meeting the WIRO requirements in respect of cost recovery.

Water plans are submitted to the ESC, which reviews them against the WIRO principles and makes a determination on water prices for the water business. In approving prices, the ECS must ensure the revenue is sufficient to allow the business to recover:

- operational, maintenance and administrative costs;

- expenditure on renewing and rehabilitating existing assets (either by classifying the expenditure as maintenance, recovering a renewals annuity or recovering the cost of financing the expenditure over time);

- a rate of return on past investments as at 1 July 2004 that are valued in a manner or at an amount determined by the Minister for Water or the costs associated with any debt incurred to finance recent expenditure in a manner determined by the Minister; and

- a rate of return on investments made after 1 July 2004 to augment existing assets or construct new assets.

The Commission must also ensure that:

- the expenditure forecasts reflect the efficient delivery of the proposed outcomes outlined in the Water Plan and take into account a planning horizon that extends beyond the regulatory period;

- the businesses have incentives to pursue efficiency improvements; and

- the prices charged or the manner in which they are to be calculated are readily understandable to customers.

The ESC recently finalised prices for the three major rural water businesses for a 5-year period starting 1 July 2008. This is the third review of prices undertaken by the ESC since it assumed responsibility for water prices in 2004. The following section describes the content of the water plan and the final pricing arrangements for the largest of Victoria's three rural water businesses, Goulburn-Murray Water.

\section{Rural Water Pricing for Goulburn-Murray Water}

Goulburn-Murray Water operates 33 separate supply services, including regulated river, channel irrigation, and piped services. The table below outlines some of the details of the business and its assets.

\footnotetext{
${ }^{10}$ The WIRO was published in the Victoria Government Gazette on 27 October 2005 and is available at www.esc.vic.gov.au.
} 
Table 3. Overview of Goulburn-Murray Water's Assets and Financials (2006-07)

\begin{tabular}{|c|c|c|}
\hline \multirow[t]{7}{*}{ Infrastructure } & Number of services & 33 \\
\hline & Regulated river & $4,317 \mathrm{~km}$ \\
\hline & Lined Channel & $6,370 \mathrm{~km}$ \\
\hline & Pipes & $545 \mathrm{~km}$ \\
\hline & Customers & 34,062 \\
\hline & Area served by system & $1,033,970 \mathrm{~km}^{2}$ \\
\hline & Volume supplied & $1,339,643 \mathrm{ML}$ \\
\hline \multirow[t]{7}{*}{ Financials } & Asset replacement costs & $\$ 2,699$ million \\
\hline & Written down replacement costs & $\$ 1,682$ million \\
\hline & Revenue from rural water services & $\$ 75$ million \\
\hline & Operational expenditure & $\$ 32$ million \\
\hline & Administration expenditure & $\$ 12$ million \\
\hline & Maintenance expenditure & \$27 million \\
\hline & Capital expenditure & $\$ 23$ million \\
\hline
\end{tabular}

Source: NWC (2008)

Goulburn Murray Water submitted its water plan to the ESC on 8 October 2007 and in June 2008 the ESC made its determination for the water prices for Goulburn Murray Water for the period 1 July 2008 to 30 June 2013. The water plan outlines:

- the proposed customer service standards (including a review of the company's past performance in achieving the required standards); and

- the revenues required to provide those services (including both operating and capital expenses).

Capital expenses - including renewal, growth and water savings projects - are to be financed through a combination of government contributions (to certain water savings projects and dam safety upgrades), as well as a return of net capital expenditure over the useful life of assets, i.e. depreciation. A return on net capital (Regulated Asset Base) is based on the weighted average cost of capital, i.e. interest on borrowings. Tariffs are then set at a level to provide the required revenue stream, based on the water demand (and availability) forecasts. The water plan proposes a revenue cap as the form of price control (i.e. the level of revenue is fixed for the regulatory period). 


\section{Separate water entitlement and delivery share}

A major restructuring of the entitlement system in Victoria has lead to the creation of separate water access shares and delivery shares. These are reflected in the tariff structure, which is outlined in the following table.

Table 4. Goulburn Murray Water Tariff Elements

\begin{tabular}{l|l|l} 
Tariff Element & Service/cost addressed by tariff & $\begin{array}{l}\text { Basis for application of tariff } \\
\text { element }\end{array}$ \\
\hline Service Fee & Recovers entitlement administration costs & per property \\
\hline $\begin{array}{l}\text { Entitlement } \\
\text { Storage Fee }\end{array}$ & $\begin{array}{l}\text { Recovers water harvesting and storage } \\
\text { costs }\end{array}$ & $\begin{array}{l}\text { per ML customer water } \\
\text { entitlement }\end{array}$ \\
\hline $\begin{array}{l}\text { Infrastructure } \\
\text { Access Fee }\end{array}$ & $\begin{array}{l}\text { Recovers fixed costs of maintaining and } \\
\text { renewing channel system }\end{array}$ & per ML/day delivery share \\
\hline $\begin{array}{l}\text { Infrastructure } \\
\text { Use Fee }\end{array}$ & $\begin{array}{l}\text { Recovers variable costs of operating channel } \\
\text { system }\end{array}$ & $\begin{array}{l}\text { per ML delivered (up to annual } \\
\text { delivery allowance) }\end{array}$ \\
\hline $\begin{array}{l}\text { Casual } \\
\text { Infrastructure } \\
\text { Use Fee }\end{array}$ & $\begin{array}{l}\text { Recovers variable costs of operating the channel } \\
\text { system and a contribution towards the fixed costs of } \\
\text { maintaining and renewing channel system }\end{array}$ & $\begin{array}{l}\text { per ML delivered (above annual } \\
\text { delivery allowance) }\end{array}$ \\
\end{tabular}

Source: Goulburn Murray Water (2008)

This new tariff structure is designed to avoid the issue of stranded assets (from trading), as well as providing the correct signals to water users about the real cost of the various services and to allows individuals to manage their own costs, whilst minimising the chances of cross subsidies.

\section{Rural water tariffs for Victorian water irrigation districts}

Annex 2 shows the water tariffs for Victoria's three major suppliers of rural water: Goulburn Murray Water, the First Mildura Irrigation Trust and Gippsland and Southern Rural Water. The tariff structures are generally similar to that described above for Goulburn Murray Water. In addition to the access, storage and usage fees listed, separate (fixed) fees apply, per account and per connection, to cover administrative and metering costs.

Note that within the Goulburn Murray Water supply area, water tariffs have historically been set at an irrigation district (rather than basin) level. Goulburn Murray Water and the ESC have indicated that they will move towards a basin-based tariff structure in the future.

\section{Cost recovery and community service obligations}

Victorian rural water authorities currently receive no CSO payments from government i.e. all schemes are at or above lower bound (NWC, 2008). As noted above, prices are set to allow recovery of both depreciation and a return on capital (using the regulated asset base), based on the weighted average cost of capital.

\section{Irrigation water pricing in New South Wales}

In New South Wales, the Department of Water and Energy ('DWE') is responsible for water resources management. Its responsibilities include preparing water sharing plans and granting and administering water access entitlements for irrigators and other water users. 
State Water Corporation is the NSW State government owned corporation responsible for bulk water supply. State Water owns and operates 20 dams and more than 280 weirs and supplies an average of 5,500 GL annually to rural NSW. State Water supplies water both directly to farmers (via regulated rivers) as well as to irrigation areas, which may take a variety of legal forms, and which in turn assume responsibility for delivering the water to irrigators within their area.

The major irrigation districts in NSW were privatised during the 1990s, with ownership and management responsibilities passed to irrigators within the districts. Key statistics for the three largest districts, as well as State Water, are listed in the table below.

The Independent Pricing and Regulatory Tribunal ('IPART') has regulatory oversight of the water sector and is responsible for setting prices for both urban and rural water services supplied by government monopoly businesses. As such, it sets prices for bulk water supply by State Water but has no role in setting prices within the private irrigation areas (except to the extent that bulk prices are passed on by the irrigation corporations' to their members).

Table 5. Major NSW providers of bulk water and rural water supply services

\begin{tabular}{|l|l|l|l|l|l|}
\hline Provider & Services & $\begin{array}{l}\text { Asset value } \\
\$\end{array}$ & $\begin{array}{l}\text { Revenue } \\
\$ / \text { year }\end{array}$ & Volume supplied & $\begin{array}{l}\text { Number of } \\
\text { customers }\end{array}$ \\
\hline State Water & $\begin{array}{l}\text { Bulk water } \\
\text { supply }\end{array}$ & $\$ 3.2 \mathrm{~b}$ & $\$ 60.3 \mathrm{~m}$ & $\begin{array}{l}5,500 \text { GL (average } \\
\text { supply) }\end{array}$ & 10,400 \\
\hline $\begin{array}{l}\text { Murray Irrigation } \\
\text { Limited }\end{array}$ & $\begin{array}{l}\text { Gravity } \\
\text { irrigation } \\
\text { scheme }\end{array}$ & $\$ 600 \mathrm{~m}$ & $\$ 21.2 \mathrm{~m}$ & $\begin{array}{l}915 \mathrm{GL} \text { (average } \\
\text { supply) }\end{array}$ & 2,405 \\
\hline $\begin{array}{l}\text { Coleambally } \\
\text { Irrigation Co- } \\
\text { operative Ltd }\end{array}$ & $\begin{array}{l}\text { Gravity } \\
\text { irrigation } \\
\text { scheme }\end{array}$ & $\$ 115 \mathrm{~m}$ & $\$ 9.8 \mathrm{~m}$ & $\begin{array}{l}629 \text { GL (bulk } \\
\text { licence volume) }\end{array}$ & 407 \\
\hline $\begin{array}{l}\text { Murrumbidgee } \\
\text { Irrigation Ltd }\end{array}$ & $\begin{array}{l}\text { Gravity } \\
\text { irrigation } \\
\text { scheme }\end{array}$ & $\$ 461 \mathrm{~m}$ & $\$ 13.7 \mathrm{~m}$ & $\begin{array}{l}412 \text { GL (06/07 } \\
\text { supply volumes) }\end{array}$ & 3,327 \\
\hline
\end{tabular}

Source: NWC (2008); Murray Irrigation Limited (2007); Coleambally Irrigation Co-operative Limited (2007)

\section{Water pricing methodology}

Prices were set by IPART in October 2006, for the period to 30 June 2010. The determination set both bulk water prices for State Water, as well as for DWE's water resource management services. Prices were set having regard to the requirements of the Independent Pricing and Regulatory Tribunal Act 1992 (NSW), which requires it to consider financial viability, economic efficiency, consumer protection and the environment, as well as NSW's obligations under the National Water Initiative.

The process of determining prices consisted of:

- Establishing the efficient costs of supplying the services

- Determining the share of these costs to be recovered from users, versus those to be paid for by the community at large via government - for example in the case of flood management or environmental protection activities

- Determining required revenues (based on a regulatory asset base approach) and sources for that revenue (users vs. government). Future capital expenditure was considered by allowing for both depreciation and a return on assets.

- Establishing price paths to achieve the revenues for the user-share component of the revenue. Tariffs were set to move prices such that, in most schemes, $40 \%$ of expected revenue will come from fixed charges, with the balance from consumptive-based charges. 


\section{Level of cost recovery}

Price paths were set to achieve cost recovery, while protecting water users against large increases in water charges over the short-term. On the current price paths, the bulk water prices for all but four basins will achieve full cost recovery by the end of the determination period. The basins where full cost recovery will be achieved represent over $95 \%$ of the total water supplied by State Water. Annex 3 summarises State Water's bulk water tariffs by basin, and shows the level of cost recovery for each.

The same process was applied to determine prices to cover the contribution of water users to DWE's water resources management costs (e.g. the cost of preparing water sharing plans and administering the water entitlements system). In the case of DWE's regulated rivers, the bulk water prices for all but two valleys will achieve full cost recovery by the end of the determination period.

\section{Water prices within irrigation corporation areas}

Due to the privatisation of the major irrigation areas, water prices for supply services within those areas are not set or regulated by government. As such, these charges are not readily accessible to the public. Annex 4 shows the tariff structure in the Murray Irrigation Corporation area, the largest irrigation area in NSW. In any case, as these districts are financially independent of government, they are required to have cost reflective pricing in place to remain financially viable.

\section{Main Policy Conclusions}

There have been major inter-governmental efforts on agricultural water pricing since the early 1990s, commencing with the signing of the first COAG Agreement in 1994. The Australian experience is rich with lessons on both the policy fundamentals, and the means by which they are implemented. Further, the continuous review of progress and ongoing work on the National Water Initiative reveals some emerging challenges.

\section{Lessons to date}

Water is a significant cost input into many businesses, and irrigated agriculture in particular. There are whole of economy benefits in ensuring water is priced properly and that its delivery and use is efficient. Water sector reforms should be seen as a key micro-economic reform, and deserve national attention.

Water pricing policies need to be developed as an integrated part of a broader reform framework, encompassing institutional changes to the way water services are delivered, and water entitlements are defined.

Cost reflective pricing for agriculture brings with it significant opposition and political difficulties. Policy frameworks need to incorporate high level inter-governmental support and commitment, fiscal incentives for State governments, and price paths to moderate effects on users. Users as owners of irrigation distribution infrastructure are more likely to accept water price increases than where they are imposed externally.

Reform processes should not be seen as short term activities, but an integral part of the policy functions of government. The reform process in Australia has been underway since before the first agreement was signed in 1994, and in many ways, activity has become more intense in recent years.

\section{Emerging challenges}

The importance of "soft" infrastructure: While there is a need to focus on the higher level policy settings around cost recovery targets and tariff structures, policy implementation and evaluation requires attention to the "soft" infrastructure meters, stream gauging networks, hydrologic and scientific support, water reporting systems, farm surveys, and benchmarking of irrigation water businesses. As the policy settings become more sophisticated, the analysis and evaluation needs to be underpinned by good information.

Moreover, water entitlements and trading requires real-time management of flows in rivers and detailed monitoring of extractions. In the longer term, a sustainable water entitlement system requires good science on river health and hydrologic performance, as well as assessments of the efficiencies of monopoly water businesses and the consequences of the reforms for agricultural production (perhaps the most important indicator of all). None of this information is obtained cheaply or easily, but without it reforms will falter. 
Water planning and management is important and needs to be funded: A well functioning water planning and management system is a pre-condition to the specification of water entitlements and water trading rules. The operation of irrigation schemes, management of entitlements within them, and the delivery and pricing of the water under those entitlements occur within frameworks administered by water resource agencies. These activities need to be properly resourced, and the NWI recognises that to the extent to which irrigators are beneficiaries, the costs should be reflected in their water prices.

A national framework for assessing and attributing these costs is under development. The implementation will be as challenging as that which occurred as part of the irrigations pricing reforms, and is as critical in ensuring the sustainability of the natural resources that support irrigated agriculture.

Lower bound pricing is not enough: There have been major price increases for irrigation supplies in Australia since 1994, and increasing acceptance amongst irrigation customers of the logic of, and need for, prices to recover costs. However, "lower bound" pricing can mean improvements in service standards are small. Capital for significant scheme efficiencies and improvements require either price increases toward upper bound, or capital subsidies to realise efficiencies. COAG has in recent years made capital subsidies to some of the larger schemes to increase efficiency, with the policy intent that volumes of water saved are returned to the environment.

Drought puts pressure on revenue streams for irrigation businesses, and costs for farmers paying fixed charges: The extended drought in parts of Australia has lead to some refinements to tariff structures. Reduced volumes have meant prices based on assumed demands have not delivered sufficient revenues to water businesses through the variable part of the tariffs. However, in many parts of the country, where no water was delivered, governments and water businesses have come under pressure from farmers' groups to rebate fixed charges.

Climate variability means a need to move beyond simple two part tariff design so revenue variability and costs to farmers can be smoothed. Options that have been considered recently include having an element of "variability" in the fixed part of the tariff, based on how much water is available. This could result in some proportion of the fixed charge being rolled over to future years if there is drought (and volumes available low). Conversely, if water availability is above a "normal' year, (and farmers have water to irrigate crops and generate income), a premium in excess of the fixed charge is paid. Ultimately, these options need to be negotiated at scheme level to consider the competing interests of the business and the farmers.

Discrete policy settings for water based on its use present difficulties: In many parts of Australia, irrigation schemes are stand-alone systems, with few urban and industrial users sharing bulk or distribution infrastructure. However, where urban and industrial customers share infrastructure with irrigators, pricing polices based on the use of the water become difficult to justify, and distort trading markets. Pricing should be based on the reliability of the product, not its end use.

Water trading means some irrigation infrastructure becoming redundant: The trading of irrigation water means that volumes may shift away from existing schemes, resulting in remaining water users paying a higher proportion of scheme costs. In the extreme, it can result in parts of schemes becoming unviable.

The Australian Competition and Consumer Commission has recently been charged with providing advice to the Federal Minister for Climate Change and Water on what level of charge (or "termination fee") should be levied on users by infrastructure owners to compensate them where the users stop using their infrastructure (e.g. where water is traded to outside of the scheme). The ACCC recently released a detailed position paper on the issue, proposing fees based on a multiple of the fixed infrastructure access charge (ACCC, 2008). Resolution of this policy issue is a high priority in removing barriers to trade.

National approaches bring risks and opportunities: Work is continuing to develop nationally consistent approaches to water pricing. There are many areas of difference, including who sets prices, how the regulatory asset base is determined, and how efficient costs are assessed. However, developing consistent approaches to these and other issues has so far required significant efforts for little gain. The more detailed and complex a policy issue is, the more difficult it is to reach consensus in an inter-governmental negotiation.

Experience in electricity sector reforms, and increasing cross-border trade in water entitlements suggest there is scope for rationalisation of State-based economic regulators and movement toward a national economic regulatory framework. The Australian Competition and Consumer Commission has recently assumed some jurisdiction for water issues in the Murray Darling Basin under the Commonwealth Water Act 2007, and may present an opportunity for further reforms in this area. 
Annex 1 . SunWater water tariffs (2008-09)

\begin{tabular}{|c|c|c|c|c|c|c|c|c|c|}
\hline $\begin{array}{l}\text { Water } \\
\text { supply } \\
\text { scheme }\end{array}$ & Basin & Description & Scheme type & $\begin{array}{l}\text { Water } \\
\text { supplied }\end{array}$ & $\begin{array}{l}\text { Average } \\
\text { volume } \\
\text { per } \\
\text { customer }\end{array}$ & $\begin{array}{l}\text { Fixed charge } \\
\text { \$/ ML } \\
\text { entitlement }\end{array}$ & $\begin{array}{l}\text { Usage } \\
\text { charge } \\
\text { \$ / ML } \\
\text { supplied }\end{array}$ & $\begin{array}{l}\text { Total } \\
\text { \$ / ML }\end{array}$ & $\begin{array}{l}\text { Recovery of } \\
\text { lower bound } \\
\text { costs }\end{array}$ \\
\hline Eton & Pioneer & $\begin{array}{l}\text { Single } 62 \mathrm{GL} \\
\text { storage. } 35 \mathrm{~km} \\
\text { open channel, } \\
\text { 130km pipeline. }\end{array}$ & $\begin{array}{l}\text { Channel and Pipeline } \\
\text { system }\end{array}$ & $\begin{array}{l}51,852 \\
(65 \% \text { usage })\end{array}$ & 185 & $\$ 37.56$ & $\$ 14.44$ & $\$ 52.00$ & $\begin{array}{l}100 \% \text { in } \\
2010 / 11\end{array}$ \\
\hline \multirow[t]{2}{*}{$\begin{array}{l}\text { Burdekin } \\
\text { Haughton }\end{array}$} & \multirow[t]{2}{*}{ Burdekin } & \multirow[t]{2}{*}{1,860 GL storage } & River System & $\begin{array}{l}103,522(85 \% \\
\text { usage) }\end{array}$ & 986 & $\$ 1.98$ & $\$ 11.59$ & $\$ 13.57$ & $100 \%$ \\
\hline & & & Channel System & $\begin{array}{l}343,060 \\
\text { (91\% usage) }\end{array}$ & 1,372 & $\$ 24.36$ & $\$ 15.61$ & $\$ 39.97$ & $100 \%$ \\
\hline \multirow[t]{2}{*}{ St George } & \multirow[t]{2}{*}{$\begin{array}{l}\text { Condamin } \\
\text { e Balonne }\end{array}$} & \multirow{2}{*}{$\begin{array}{l}100 \text { GL (1 dam, } 3 \\
\text { weirs). } 32 \mathrm{~km} \\
\text { gravity channels }\end{array}$} & River System & $\begin{array}{l}20,913 \\
\text { (85\% usage) } \\
\end{array}$ & 174 & $\$ 13.64$ & $\$ 2.83$ & $\$ 16.47$ & $100 \%$ \\
\hline & & & Channel System & $\begin{array}{l}50,770 \\
\text { (95\%usage) }\end{array}$ & 976 & $\$ 27.81$ & $\$ 10.04$ & $\$ 37.85$ & $100 \%$ \\
\hline $\begin{array}{l}\text { Dawson } \\
\text { Valley }\end{array}$ & Fitzroy & $\begin{array}{l}6 \text { weirs and } 56 \\
\mathrm{~km} \text { of channels }\end{array}$ & River system & $\begin{array}{l}36,355 \\
\text { (55\% usage) }\end{array}$ & 319 & $\$ 8.86$ & $\$ 9.01$ & $\$ 17.87$ & $>100 \%$ \\
\hline
\end{tabular}




\begin{tabular}{|c|c|c|c|c|c|c|c|c|c|}
\hline $\begin{array}{l}\text { Callide } \\
\text { Valley }\end{array}$ & Fitzroy & $\begin{array}{l}\text { Two dams } \\
(136,700 \mathrm{ML} \text { and } \\
14,600) \text { for } \\
\text { groundwater } \\
\text { recharge }\end{array}$ & $\begin{array}{l}\text { Groundwater and } \\
\text { river system }\end{array}$ & $\begin{array}{l}18,255 \\
\text { (50\% usage) }\end{array}$ & 121 & $\begin{array}{l}\$ 3.10 \\
\text { (Increasing to } \\
\$ 5 \text { by } \\
2010 / 11 \text { ) }\end{array}$ & $\begin{array}{l}\$ 18.20 \\
\text { (Increasing } \\
\text { to } \$ 21.05 \\
\text { by } \\
2010 / 11 \text { ) }\end{array}$ & $\begin{array}{l}\$ 21.30 \\
\text { (Increasi } \\
\text { ng to } \\
\$ 26.05 \\
\text { by } \\
2010 / 11 \text { ) }\end{array}$ & $46 \%$ \\
\hline \multirow[t]{2}{*}{$\begin{array}{l}\text { Nogoa } \\
\text { Mackenzie }\end{array}$} & \multirow[t]{2}{*}{ Fitzroy } & \multirow{2}{*}{$\begin{array}{l}\text { Major storage, } 4 \\
\text { weirs, } 126 \mathrm{~km} \text { of } \\
\text { channel }\end{array}$} & River system & $\begin{array}{l}77,652 \\
\text { (85\% usage) }\end{array}$ & 300 & $\$ 4.98$ & $\$ 6.59$ & $\$ 11.52$ & $>100 \%$ \\
\hline & & & Channel system & $\begin{array}{l}95,041 \\
\text { (80\% usage) }\end{array}$ & 306 & $\$ 17.16$ & $\$ 12.47$ & $\$ 29.63$ & $>100 \%$ \\
\hline $\begin{array}{l}\text { Upper } \\
\text { Mary }\end{array}$ & Mary & $\begin{array}{l}46,000 \mathrm{ML} \\
\text { storage }\end{array}$ & River & $\begin{array}{l}17,674 \\
\text { (40\% usage) }\end{array}$ & 79 & $\$ 11.42$ & $\$ 7.14$ & $\$ 18.56$ & $79 \%$ \\
\hline \multirow[t]{3}{*}{$\begin{array}{l}\text { Lower } \\
\text { Mary }\end{array}$} & \multirow[t]{3}{*}{ Mary } & \multirow{3}{*}{$\begin{array}{l}\text { Weir, barrage, } \\
\text { channel and } \\
\text { pipeline system }\end{array}$} & River & $\begin{array}{l}8,578 \\
\text { (60\%usage) }\end{array}$ & 134 & $\$ 11.8$ & $\$ 8.43$ & $\$ 20.23$ & $100 \%$ \\
\hline & & & River & $\begin{array}{l}5,358 \\
\text { (47\% usage) }\end{array}$ & 134 & $\$ 8.04$ & $\$ 8.58$ & $\$ 16.62$ & $>100 \%$ \\
\hline & & & Channel & $\begin{array}{l}8,148 \\
(60 \% \text { usage })\end{array}$ & 93 & $\$ 34.90$ & $\$ 24.93$ & $\$ 59.83$ & $100 \%$ \\
\hline Bundaberg & Burnett & $\begin{array}{l}562,000 \mathrm{ML} \\
\text { storage, } 1000 \mathrm{~km} \\
\text { of channel }\end{array}$ & Channel & $\begin{array}{l}149,026 \\
\text { (60\% usage) }\end{array}$ & 168 & $\$ 36.34$ & $\$ 25.96$ & $\$ 62.30$ & $100 \%$ \\
\hline \multirow[t]{2}{*}{$\begin{array}{l}\text { Upper } \\
\text { Burnett }\end{array}$} & \multirow[t]{2}{*}{ Burnett } & \multirow[t]{2}{*}{$\begin{array}{l}165,400 \mathrm{ML} \\
\text { storage, } 3 \text { weirs }\end{array}$} & River & $\begin{array}{l}28,139 \\
\text { (70\% usage) }\end{array}$ & 166 & $\$ 14.94$ & $\$ 9.14$ & $\$ 24.08$ & $72 \%$ \\
\hline & & & River (Golby Weir) & $\begin{array}{l}1,560 \\
\text { (70\%usage) }\end{array}$ & 166 & $\$ 13.66$ & $\$ 18.64$ & $\$ 32.30$ & $>100 \%$ \\
\hline \multirow[t]{2}{*}{$\begin{array}{l}\text { Barker } \\
\text { Barambah }\end{array}$} & \multirow[t]{2}{*}{ Burnett } & \multirow{2}{*}{$\begin{array}{l}134,900 \mathrm{ML} \\
\text { storage, weir, } 6.2 \\
\text { km pipeline }\end{array}$} & Re-lift scheme & $\begin{array}{l}1,627 \\
(70 \%)\end{array}$ & 173 & $\$ 14.38$ & $\$ 23.68$ & $\$ 38.06$ & $67 \%$ \\
\hline & & & River & $\begin{array}{l}29,453 \\
\text { (75\% usage) }\end{array}$ & 173 & $\$ 16.78$ & $\$ 9.59$ & $\$ 26.37$ & $\begin{array}{l}100 \% \text { in } \\
2010 / 11\end{array}$ \\
\hline Logan & Logan & $\begin{array}{l}43,300 \mathrm{ML} \\
\text { storage, } 2 \text { weirs }\end{array}$ & River & $\begin{array}{l}13,532 \\
\text { (55\% usage) }\end{array}$ & 96 & $\$ 14.14$ & $\$ 22.57$ & $\$ 36.71$ & $>100 \%$ \\
\hline
\end{tabular}




\begin{tabular}{|c|c|c|c|c|c|c|c|c|c|}
\hline $\begin{array}{l}\text { Central } \\
\text { Lockyer }\end{array}$ & Moreton & $\begin{array}{l}3 \text { small storages, } \\
\text { approx } 32 \mathrm{GL} \text {. For } \\
\text { groundwater } \\
\text { recharge and to } \\
\text { supplement river } \\
\text { supply }\end{array}$ & $\begin{array}{l}\text { River and } \\
\text { groundwater }\end{array}$ & $\begin{array}{l}12,700 \\
\text { (65\% usage) }\end{array}$ & 62 & $\begin{array}{l}\$ 5.25 \\
\text { (Increasing to } \\
\$ 10 \text { by } \\
20010 / 11 \text { ) }\end{array}$ & $\$ 26.59$ & $\$ 31.84$ & $61 \%$ \\
\hline $\begin{array}{l}\text { Lower } \\
\text { Lockyer }\end{array}$ & Moreton & & River & $\begin{array}{l}11,196 \\
(35 \%)\end{array}$ & & $\$ 17.65$ & $\$ 21.62$ & $\$ 39.27$ & $36 \%$ \\
\hline $\begin{array}{l}\text { Warrill } \\
\text { Valley }\end{array}$ & Moreton & $\begin{array}{l}83,700 \mathrm{ML} \\
\text { storage, } 8 \text { weirs }\end{array}$ & River system & $\begin{array}{l}20,503 \\
\text { (55\% usage) }\end{array}$ & 73 & $\$ 15.32$ & $\$ 18.07$ & $\$ 33.39$ & $>100 \%$ \\
\hline \multirow[t]{4}{*}{$\begin{array}{l}\text { Mareeba } \\
\text { Dimbulah }\end{array}$} & \multirow[t]{4}{*}{ Barron } & \multirow[t]{4}{*}{$\begin{array}{l}438,900 \mathrm{ML} \\
\text { storage, } 365 \mathrm{~km} \\
\text { channel }\end{array}$} & $\begin{array}{l}\text { River system } \\
\text { (Supplemented and } \\
\text { Walsh) }\end{array}$ & $\begin{array}{l}27,962 \\
(67.5 \% \text { usage })\end{array}$ & 90 & $\$ 14.21$ & $\$ 10.17$ & $\$ 24.38$ & $>100 \%$ \\
\hline & & & $\begin{array}{l}\text { River system } \\
\text { (Tinaroo/Barron) }\end{array}$ & $\begin{array}{l}5,833 \\
\text { (50\% usage) }\end{array}$ & 90 & $\$ 2.71$ & $\$ 13.66$ & $\$ 16.27$ & $>100 \%$ \\
\hline & & & $\begin{array}{l}\text { Channel (Outside re- } \\
\text { lift, >500ML) }\end{array}$ & $\begin{array}{l}48,025 \\
(67.5 \% \text { usage })\end{array}$ & 90 & $\$ 18.99$ & $\$ 12.06$ & $\$ 31.05$ & $100 \%$ \\
\hline & & & Channel (re-lift) & $\begin{array}{l}8,140 \\
(67.5 \% \text { usage })\end{array}$ & 90 & $\$ 34.49$ & $\$ 21.90$ & $\$ 56.39$ & $58 \%$ \\
\hline
\end{tabular}

Source: SunWater (2006)

Note: Water supplied is the total nominal volume allocated for the scheme, together with the estimated annual usage. Together these figures were used to calculate the tariffs 


\section{Annex 2. Victorian rural water tariffs 2008/09}

\begin{tabular}{|c|c|c|c|c|c|c|c|c|c|}
\hline $\begin{array}{l}\text { Supply } \\
\text { region }\end{array}$ & $\begin{array}{l}\text { Irrigation } \\
\text { district/area }\end{array}$ & $\begin{array}{l}\text { Scheme } \\
\text { type }\end{array}$ & $\begin{array}{l}\text { Volume } \\
\text { supplied } \\
\text { ML/yr }\end{array}$ & $\begin{array}{l}\text { Average } \\
\text { volume/ } \\
\text { custome } \\
\text { r } \\
\text { ML }\end{array}$ & 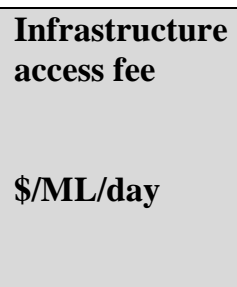 & $\begin{array}{l}\text { Infrastruct } \\
\text { ure use fee }\end{array}$ & $\begin{array}{l}\begin{array}{l}\text { Casual } \\
\text { infrastructure } \\
\text { use fee }\end{array} \\
\text { \$/ML }\end{array}$ & $\begin{array}{l}\text { Entitlement storage } \\
\text { fee } \\
\text { (HR: High } \\
\text { Reliability } \\
\text { LR: Low } \\
\text { Reliability) } \\
\text { \$/ML }\end{array}$ & $\begin{array}{l}\text { Recovery } \\
\text { of lower } \\
\text { bound } \\
\text { costs }\end{array}$ \\
\hline \multirow[t]{4}{*}{$\begin{array}{l}\text { Goulburn } \\
\text { Murray } \\
\text { Water }\end{array}$} & $\begin{array}{l}\text { Shepparton } \\
\text { Gravity } \\
\text { Irrigation }\end{array}$ & Channel & 69,203 & 29 & $3,288.82$ & 8.64 & 62.29 & $\begin{array}{l}\mathrm{HR}-5.13 \\
\mathrm{LR}-2.78\end{array}$ & $\geq 100 \%$ \\
\hline & $\begin{array}{l}\text { Central } \\
\text { Goulburn } \\
\text { Gravity } \\
\text { Irrigation }\end{array}$ & $\begin{array}{l}\text { Gravity } \\
\text { channel }\end{array}$ & 156,636 & 42 & $3,038.64$ & 6.60 & 55.48 & $\begin{array}{l}\mathrm{HR}-5.13 \\
\mathrm{LR}-2.78\end{array}$ & $\geq 100 \%$ \\
\hline & $\begin{array}{l}\text { Rochester } \\
\text { Gravity } \\
\text { Irrigation }\end{array}$ & $\begin{array}{l}\text { Gravity } \\
\text { channel }\end{array}$ & 67,565 & 42 & $2,538.28$ & 6.95 & 48.5 & $\begin{array}{l}\mathrm{HR}-5.13 \\
\mathrm{LR}-2.78\end{array}$ & $\geq 100 \%$ \\
\hline & $\begin{array}{l}\text { Pyramid- } \\
\text { Boort } \\
\text { Gravity } \\
\text { Irrigation }\end{array}$ & $\begin{array}{l}\text { Gravity } \\
\text { channel }\end{array}$ & 67,424 & 82 & $1,876.35$ & 6.75 & 38.28 & $\begin{array}{l}\mathrm{HR}-5.13 \\
\mathrm{LR}-2.78\end{array}$ & $\geq 100 \%$ \\
\hline
\end{tabular}




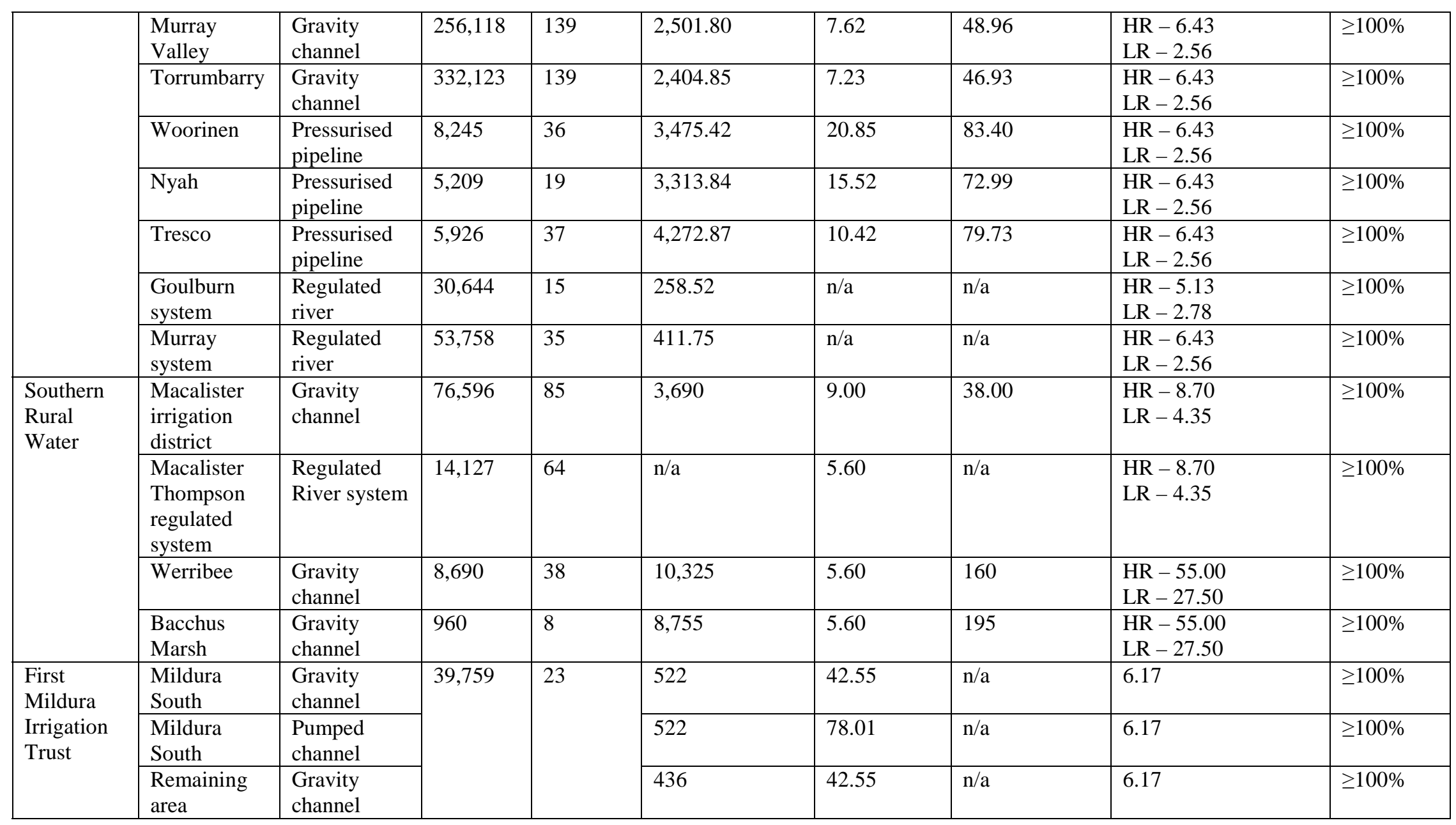

Source: Essential Services Commission pricing determinations (2008) 
Annex 3. New South Wales (State Water) bulk water tariffs 2008/09

\begin{tabular}{|c|c|c|c|c|c|c|c|c|c|}
\hline Basin & $\begin{array}{l}\text { Water } \\
\text { Supply } \\
\text { System } \\
\text { Type }\end{array}$ & $\begin{array}{l}\text { Volume } \\
\text { supplied } \\
\text { ML/yr }\end{array}$ & $\begin{array}{l}\text { Average } \\
\text { volume } \\
\text { per } \\
\text { customer } \\
\text { account } \\
\text { ML } \\
\end{array}$ & $\begin{array}{l}\text { Fixed } \\
\text { charge - } \\
\text { High } \\
\text { Security } \\
\text { \$/ML }\end{array}$ & $\begin{array}{l}\text { Fixed } \\
\text { charge - } \\
\text { General } \\
\text { Security } \\
\text { \$/ML }\end{array}$ & $\begin{array}{l}\text { Variable } \\
\text { \$/ML }\end{array}$ & $\begin{array}{l}\text { Total } \\
\text { \$/ML }\end{array}$ & $\begin{array}{l}\text { Lower } \\
\text { bound cost } \\
\text { recovery } \\
06 / 07\end{array}$ & $\begin{array}{l}\text { Lower } \\
\text { bound cost } \\
\text { recovery } \\
09 / 10\end{array}$ \\
\hline Border & $\begin{array}{l}\text { Regulated } \\
\text { river }\end{array}$ & 209,670 & 1519 & 4.01 & 3.03 & 5.31 & 8.84 & $61 \%$ & $100 \%$ \\
\hline Gwydir & $\begin{array}{l}\text { Regulated } \\
\text { river }\end{array}$ & 309,164 & 702 & 5.27 & 3.02 & 7.06 & 10.08 & $70 \%$ & $100 \%$ \\
\hline Namoi & $\begin{array}{l}\text { Regulated } \\
\text { river }\end{array}$ & 237,146 & 364 & 8.42 & 6.48 & 10.32 & 16.80 & $76 \%$ & $100 \%$ \\
\hline Peel & $\begin{array}{l}\text { Regulated } \\
\text { river }\end{array}$ & 14,675 & 76 & 10.76 & 2.38 & 20.20 & 22.58 & $40 \%$ & $45 \%$ \\
\hline Lachlan & $\begin{array}{l}\text { Regulated } \\
\text { river }\end{array}$ & 307,149 & 197 & 6.28 & 2.91 & 8.63 & 11.54 & $85 \%$ & $100 \%$ \\
\hline Macquarie & $\begin{array}{l}\text { Regulated } \\
\text { river }\end{array}$ & 386,311 & 260 & 4.91 & 2.81 & 6.83 & 9.64 & $77 \%$ & $100 \%$ \\
\hline Murray & $\begin{array}{l}\text { Regulated } \\
\text { river }\end{array}$ & $1,934,830$ & 638 & 2.97 & 2.49 & 3.06 & 5.55 & $100 \%$ & $100 \%$ \\
\hline Murrumbidgee & $\begin{array}{l}\text { Regulated } \\
\text { river }\end{array}$ & $1,915,848$ & 1247 & 2.49 & 1.79 & 2.68 & 4.47 & $88 \%$ & $100 \%$ \\
\hline Hunter & $\begin{array}{l}\text { Regulated } \\
\text { river }\end{array}$ & 128,067 & 931 & 15.74 & 5.84 & 9.72 & 15.56 & $52 \%$ & $88 \%$ \\
\hline South Coast & $\begin{array}{l}\text { Regulated } \\
\text { river }\end{array}$ & 5,831 & 65 & 9.93 & 6.29 & 18.78 & 25.07 & $22 \%$ & $29 \%$ \\
\hline
\end{tabular}

Source: IPART (2006)

Note: "Volume supplied" is the estimated consumption that was used by IPART in determining price 
Annex 4. New South Wales (Murray Irrigation District) water tariffs 2007/08

\begin{tabular}{|c|c|c|c|c|c|c|c|c|}
\hline \multirow{2}{*}{$\begin{array}{l}\text { Water Supply } \\
\text { Scheme }\end{array}$} & \multirow{2}{*}{$\begin{array}{l}\text { Water } \\
\text { Supply } \\
\text { System Type }\end{array}$} & \multirow{2}{*}{$\begin{array}{l}\text { Volume } \\
\text { supplied } \\
\text { ML/yr }\end{array}$} & \multirow[b]{2}{*}{$\begin{array}{l}\text { Average } \\
\text { volume per } \\
\text { customer } \\
\text { account } \\
\text { ML/user }\end{array}$} & \multicolumn{2}{|c|}{ Bulk supply charges } & \multicolumn{2}{|c|}{ District supply charges } & \multirow{2}{*}{$\begin{array}{l}\text { 08/09 Tariff } \\
\text { Total } \\
\text { \$/ML }\end{array}$} \\
\hline & & & & $\begin{array}{l}\text { Fixed } \\
\text { charge } \\
\$ / \mathrm{ML}\end{array}$ & $\begin{array}{l}\text { Variable } \\
\text { \$/ML }\end{array}$ & $\begin{array}{l}\text { Fixed } \\
\text { charge } \\
\text { \$/ML }\end{array}$ & $\begin{array}{l}\text { Variable } \\
\text { \$/ML }\end{array}$ & \\
\hline $\begin{array}{l}\text { Murray Irrigation } \\
\text { District }\end{array}$ & Channel & $1,200,000$ & 498 & 3.17 & 3.52 & 9.47 & 10.18 & 23.17 \\
\hline
\end{tabular}

Source: Murray Irrigation Limited (2007) 


\section{Bibliography}

National Water Commission (NWC) (2006), National Competition Policy Assessment of Water Reform Progress, www.nwc.gov.au/www/html/511-2005-national-competition-policy-assessment-of-waterreform-progress.asp?intSiteID=1

Australian Bureau of Statistics (ABS) (2008), Water Use on Australian Farms, 2006-07, www.abs.gov.au/AUSTATS/abs@nsf/detailspage/4618.02007-7?OpenDocument.

Australian Competition and Consumer Commission (ACCC) (2008), Position paper: Water charge rules for termination fees, www.accc.gov.au/content/index.phtml/itemId/839389

Coleambally Irrigation Co-operative Limited (2007), Annual Report for the year ended 30 June 2007, www.colyirr.com.au/AboutCICL/index.asp;

Council of Australian Government (COAG) (2004), Intergovernmental agreement on a National Water Initiative. 25 June 2004, www.nwc.gov.au/resources/documents/Intergovernmental-Agreement-on-anational-water-initiative.pdf

Essential Services Commission (Vic) (2008), 2008 Water Price Review Final Decision: GWMWater Determination, June, www.esc.vic.gov.au

Essential Services Commission (Vic) (2008), 2008 Water Price Review Final Decision: Southern Rural Water Determination, June, www.esc.vic.gov.au

Essential Services Commission (Vic) (2008), 2008 Water Price Review Final Decision: FMIT Determination, June, www.esc.vic.gov.au

Goulburn-Murray Water (2008), Goulburn-Murray Water 2008 Water Plan, www.g-mwater.com.au/about/reports-and-publications/gmwwaterplans

Independent Pricing and Regulatory Tribunal New South Wales (IPART) (2006), Bulk Water Prices for State Water Corporation and Water Administration Ministerial Corporation from 1 October 2006 to 30 June 2010: Water - Report, September 2006, www.ipart.nsw.gov.au

Murray Irrigation Limited, (2007), 2007/08 Pricing Schedule, www.murrayirrigation.com.au/files/3291000.pdf

Murray Irrigation Limited (2008), Historical Water Usage Data, www.murrayirrigation.com.au/content.aspx $? \mathrm{p}=20026$

National Competition Council (1998), Compendium of National Competition Policy Agreements Second Edition, June 1998, Australia

National Water Commission (2007a), Cost recovery for water storage and delivery charges: Report prepared the National Water Initiative Steering Group on Water Charges, www.nwc.gov.au/www/html/401-intro.asp

National Water Commission (2007b), Cost recovery for water planning and management in Australia: Report of the National Water Initiative Steering Group on Water Charges, www.nwc.gov.au/www/html/401-intro.asp

National Water Commission (2008), National Performance Report, 2006-2007, Rural Water Service Providers, www.nwc.gov.au/nwi/national_performance_reports.cfm

SunWater (2006), SunWater Irrigation Price Paths 2006/07 - 2010/11. Final Report, www.sunwater.com.au/irrigationpricing_final_report.htm 